\title{
BIOLOGICAL TREATMENT OF TANNERY EFFLUENT USING CYANOBACTERIA AND NRK FOR SANSEVIERIA TRIFASCIATA PLANT GROWTH
}

\author{
Mohamed Riyaz. S. ${ }^{1}$, Sowmya. $\mathbf{R}^{2}$, Jenifer. G. ${ }^{3}$, Ketut Gede Dharma Putra ${ }^{4}$ \\ Jenny. S. ${ }^{5}$ and Malliga. P. ${ }^{6 *}$ \\ ${ }^{1}$ Department of Biotechnology, \\ Pavendar Bharathidasan College of Engineering and Technology, Tiruchirappalli, India \\ ${ }^{283}$ Department of Marine Biotechnology, Bharathidasan University, Tiruchirappalli, India \\ ${ }^{4}$ Centre for Sustainable Development, Udayana University, Bali, Indonesia \\ ${ }^{5}$ Assistant Professor, Department of Microbiology, Cauvery College for Women, Tiruchirappalli, India \\ ${ }^{*}$ Professor \& Head, Department of Marine Biotechnology, Bharathidasan University, \\ Tiruchirappalli, India *Email: malliga.p@bdu.ac.in
}

\begin{abstract}
The leather industries are regarded as one of the major contributors of industrial pollution as the effluent discharged is highly putrescible volume and when untreated damages the normal life of the receiving stream. The present study aims to ameliorate hazards and waste products into applicable organic manure by the combined treatment of tannery effluent, cyanobacteria, coir pith and Nava Rasa Karaisal (NRK). The genus "Sansevieria" has been anciently used for various health alignments (inflammation, anti-allergic reactions and antivenom) all over the world especially in China, African countries and tropical America. In recent years, the people are encountering major health hazards and challenges due to air pollution and pollutants released from tannery. Thus, this study aims at the plant Sansevieria trifasciata (capable of absorbing toxins from air and releases $\mathrm{O}_{2}$ at night) was grown by using manure obtained from combined treatment as basal application. The physiochemical, biochemical and SEM analysis were done on $50^{\text {th }}$ day while morphological parameters (shoot length and width, no. of leaves) at indoor and outdoor light intensity were monitored on initial and $50^{\text {th }}$ day. The obtained results showed reduction in physiochemical and heavy metal contents after combined treatment of tannery effluent. The morphometric parameter analysis also showed increased plant growth after combined treatment in indoor plants when compared to outdoor plants.
\end{abstract}

Key words: Tannery, Lyngbya sp., coir pith, NRK, Sansevieria trifasciata, Growth Study

\section{Introduction}

Leather industry is one of the oldest industries in India and one of the leading foreign exchange earners for the country. But the industry is plagued by heavy pollution stress on the environment, thus negating some of the other societal benefits the industry has merited. Production of leather, leather goods, boards and fur produces numerous by-product, solid waste, and high amount of wastewater containing different loads of pollutants. Thus, these industries are considered to be one of the major contributors of industrial pollution (Alebelabebe, 2010). During the conversion, a series of chemical processes and physical operations are carried out to attain the final desired properties of leathers. Pre-tanning, tanning and post-tanning are the major steps involved in leather processing (Ganesh and Ramanujam, 2009). Abirami et al. (2013) reported that majority of industry is water based and considerable volume of waste water is discharged into the environment either untreated or inadequately treated which leads to the problem of surface and ground water pollution. To overcome this problem, some physical and chemical methods, such as reverse osmosis, ion exchange, membrane filtration and electro dialysis are used effectively for removing but they are expensive and generating concentrated wastes that require subsequent treatment and disposal. Biological removal may provide a suitable means for treatment from wastewater (Murali et al., 2013).There has been an increasing concern over dangerous levels of heavy metals contaminating the environment. Increase in environmental contamination leads to a progressive deterioration of environmental quality. This condition challenges us to find effective measures of remediation.

Bioremediation is an eco-friendly and natural technology targeted to eliminate heavy metals, radionuclide, xenobiotic compounds, organic waste, pesticides etc. from contaminated 
sites or industrial discharges through biological means (David and Rajan, 2012) The application of cyanobacteria showed immense potential in waste water and industrial effluent treatment, bioremediation of aquatic, terrestrial habitat, chemical industries, bio fertilizers, food, feed, fuel etc. Cyanobacteria also known as blue green algae are ubiquitous in nature and distributed group of prokaryotic photoautotroph microorganism (Sanjay et al., 2011). They are gram negative filamentous or unicellular that grows as mats on the surface of bare soil as primary colonizers. The cyanobacteria Oscillatoria annae grows luxuriantly along with coir pith in field condition (Anandhraj et al., 2012).

Coir pith is the by-product of coir yarn industries which constitute about $70 \%$ husk. As coir pith has high content of lignin and it takes decades to decompose, it causes environmental hazards because of its disposal problems (Krishnamoorthy et al., 2012).The recent research shows that coir pith can be partially decomposed through the action of cyanobacteria and can be used as biofertilizer for all varieties of food crops (Jenny and Malliga, 2016). Nava Rasa Karaisal is a concoction prepared by mixing of nine products and used in traditional rituals. It enriches the soil and provides the entire nutrient required for the growth of the plant. Physicochemical and biological properties of Nava Rasa Karaisal revealed that they posses almost all the macro nutrients, micro nutrients and growth hormones required for crop growth. Nava Rasa Karaisal is a rich source of nitrogen and valuable microorganisms which naturally enhances soil fertility. The seven species of the genus Sansevieria, monocots in the family Asparagaceae are popular ornamental evergreen perennials characterized by vertically elongated rigid leaves arranged in a rosette around a single growing point, with distinct dark cross-banded coloration patterns (Gautham et al., 2012). The Snake Plant, or Mother-in-Law's Tongue, is one of the most recommended plants for improving air quality (Gargi et al., 2017).The NASA conducted a study to evaluate the uses of snake plant. According to their results they found out that the snake plant absorbs toxins, such as nitrogen oxides and formaldehyde. Sansevieria trifasciata is able to absorb 107 types of toxins, including the toxins generated from air pollution, cigarette smoke (nicotine), which would make a great refresher (Julie et al., 2017). The snake plant (Sansevieria trifasciata) was also evaluated for their species effectiveness in reducing ozone concentrations in a simulated indoor environment (Heather et al., 2009).

\section{MATERIALS AND METHODS}

\section{Effluent Collection}

The tannery effluent was collected from a tannery industrial unit situated at Sempattu, Tiruchirappalli, Tamil Nadu, India.

\section{Lignocellulosic Waste}

Coir pith was collected from coir industries near Srirangam, Tiruchirappalli, Tamil Nadu, India.

\section{Organism and Source}

Filamentous, non-heterocystous marine cyanobacteria Lyngbya sp. was obtained from the germplasm collections of National Facility for Marine Cyanobacteria (NFMC), Department of Marine Biotechnology, Bharathidasan University, Tiruchirappalli, Tamil Nadu, India.

\section{Media and Growth Conditions}

The obtained cyanobacteria was cultivated and maintained under laboratory conditions with temperature of $25 \pm 2^{\circ} \mathrm{C}$ and light requirement of 1500 lux with light/dark cycle of $14 / 10 \mathrm{hr}$. illuminated with fluorescent tubes, sustained in the respective ASN III medium (Rippka et al., 1979).

\section{Treatment}

In this study, water was used as control. For combined treatment, the raw tannery effluent was inoculated with cyanobacterium and also in combination with coir pith and incubated for 20 days. After incubation, the obtained pellet was treated with Nava Rasa Karaisal and incubated for 10 days for further degradation and used as basal manure for plant treatment. The physiochemical parameters, heavy metal and nutritive factor analysis were carried out on $30^{\text {th }}$ day of the study period. 


\section{Determination of $\mathrm{pH}$}

The $\mathrm{pH}$ of the sample was determined using $\mathrm{pH}$ meter which has been initially standardized by buffer solution of known value before analysis.

\section{Determination of COD and BOD}

The COD and BOD were measured according to the standard methods (APHA, 1998).

\section{Estimation of Heavy Metals}

The heavy metals like Iron, Chromium, Nickel, Cadmium, Lead, Selenium, Arsenic, Fluoride, Copper, Manganese, Mercury and Zinc were estimated according to the standard methods (AOAC, 2000)

\section{Estimation of Nutritive Factor}

The NPK levels were estimated using standard methods; Nitrogen (Jackson et al., 2001), Potassium (Hald, 1947) and phosphorous (APHA, 1998).

\section{SEM Analysis}

The SEM analysis was performed to identify the adherence of particles (size $10 \mu \mathrm{m}$ and $2 \mu \mathrm{m}$ ) on the untreated and treated tannery effluent on $30^{\text {th }}$ day of the study period.

\section{Pot Experiment}

The pot experiment was conducted to analyze the growth of the plant Sansevieria trifasciata. The $1 \mathrm{~kg}$ pot was prepared with combination of manure, coir pith and soil in 1:2:2 ratio. One set of plants were kept in outdoor at a light intensity about 15,000 lux and the other set of plants were kept at indoor light intensity about 500 lux. The plants were washed thrice to remove all the traces of extra leaf of the plant. The initial and final $\left(50^{\text {th }}\right.$ day study) morphometric parameters (shoot length and width, No. of leaves) were monitored for both set of plants. Thus, the aim of this study was to investigate the effect of untreated and treated tannery effluent on plant growth and its morphometric parameters.

\section{RESULT AND DISCUSSION}

\section{Determination of Physiochemical Parameters}

The $\mathrm{pH}$ was observed to be mild acidic in nature and on $30^{\text {th }}$ day, the $\mathrm{pH}$ of untreated (TN) and treated tannery effluent $(\mathrm{TN}+\mathrm{CP}+\mathrm{CB}+\mathrm{NRK})$ value showed as 8.87 and 6.56. The $\mathrm{BOD}$ and $\mathrm{COD}$ levels were greatly reduced in combined treatment $(\mathrm{TN}+\mathrm{CP}+\mathrm{CB}+\mathrm{NRK})$ on $50^{\text {th }}$ day analysis when compared with untreated tannery effluent. The BOD levels were $356 \mathrm{mg} / \mathrm{l}$ (TN), 290mg/l (T.TN) while COD levels were observed to be $1.98 \mathrm{~g} / \mathrm{l}$ (TN), $1.404 \mathrm{~g} / \mathrm{l}$ (T.TN) respectively (Fig.1). The findings were similar to the observations of Anamika et al. (2013) which showed that the values of BOD and COD of untreated tannery effluent to be $1.2 \mathrm{~g} / \mathrm{l}$ and $2.3 \mathrm{~g} / \mathrm{l}$ respectively and levels of $\mathrm{BOD}$ and $\mathrm{COD}$ were reduced after treatment with Pseudomonas sp. to $0.9 \mathrm{~g} / \mathrm{l}$ and $0.3 \mathrm{~g} / \mathrm{l}$ respectively on $20^{\text {th }}$ day. The BOD and COD levels were recorded as 340 and $610 \mathrm{mg} / \mathrm{l}$ respectively with untreated tannery effluent but after inoculation with Pseudomonas sp. the levels were reduced to 90 and $220 \mathrm{mg} / \mathrm{l}$ respectively on $15^{\text {th }}$ day (Srinivas and Estari, 2012).

\section{Figure 01: Effect of Basal Treatment on (a) BOD (b) COD}

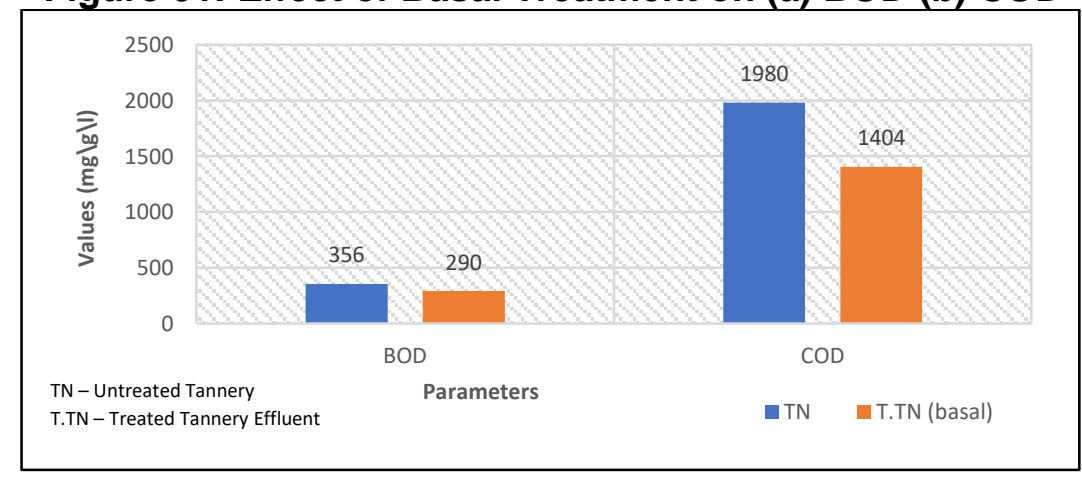

\section{Estimation of Heavy Metals}

The presence of heavy metals like Iron $(20.5 \mathrm{mg} / \mathrm{l})$, Chromium $(84.6 \mathrm{mg} / \mathrm{l})$, Lead $(10.3 \mathrm{mg} / \mathrm{l})$ and Nickel $(6.7 \mathrm{mg} / \mathrm{l})$ were observed in untreated tannery effluent. But after combined treatment $(\mathrm{TN}+\mathrm{CB}+\mathrm{CP}+\mathrm{NRK})$, a reduction in the levels of heavy metals like Iron $(14.68 \mathrm{mg} / \mathrm{kg})$, Chromium 
$(2.73 \mathrm{mg} / \mathrm{kg})$, Lead $(2.2 \mathrm{mg} / \mathrm{kg})$ and Nickel $(3.72 \mathrm{mg} / \mathrm{kg})$ were observed (Fig. 2a). Similarly, the presence of heavy metals like Mercury $(1.20 \mathrm{mg} / \mathrm{l})$, Cadmium $(10.0 \mathrm{mg} / \mathrm{l})$, Copper $(25.0 \mathrm{mg} / \mathrm{l})$ and Zinc $(12.4 \mathrm{mg} / \mathrm{l})$ in untreated tannery effluent were reduced into Mercury $0.56 \mathrm{mg} / \mathrm{kg}$, Cadmium $(3.98 \mathrm{mg} / \mathrm{kg})$, Copper $(0.85 \mathrm{mg} / \mathrm{kg})$ and Zinc $(2.22 \mathrm{mg} / \mathrm{kg})$ in combined treatment $(\mathrm{TN}+\mathrm{CB}+\mathrm{CP}+\mathrm{NRK})$ (Fig. 2b). The levels of Arsenic (2.8mg/l), Fluoride (12.0mg/l), Manganese $(5.6 \mathrm{mg} / \mathrm{l})$ and Selenium $(5.5 \mathrm{mg} / \mathrm{l})$ in untreated tannery effluent were reduced as Arsenic $(1.16 \mathrm{mg} / \mathrm{kg})$, Fluoride $(11.5 \mathrm{mg} / \mathrm{kg})$, Manganese $(2.85 \mathrm{mg} / \mathrm{kg})$ and Selenium $(1.84 \mathrm{mg} / \mathrm{kg})$ when treated with the microbial consortium (Fig. 2c).

Sharma and Malaviya (2011) revealed that high level of chromium $(9.86 \mathrm{mg} / \mathrm{l})$ was present in untreated tannery effluent but after treatment with Fusarium chlamydosporium, the level was reduced $(0.00 \mathrm{mg} / \mathrm{l})$ respectively on $6^{\text {th }}$ day. Selvi et al. (2012) also reported higher reduction of $\mathrm{Pb}(90 \%), \mathrm{Cu}(85 \%), \mathrm{Zn}(80 \%), \mathrm{Cr}(70 \%)$ and $\mathrm{Hg}(80 \%)$ from tannery effluent using isolated strains of Pseudomonas sp. All heavy metals were found to be reduced with all the treatments notably with the combined treatment of Lyngbya sp. with coir pith in tannery effluent due to absorption of heavy metal particles on the surface of Lyngbya sp. and coir pith (Lakshmi et al., 2015)

Figure 02: Effect of Basal Treatment on Heavy Metals
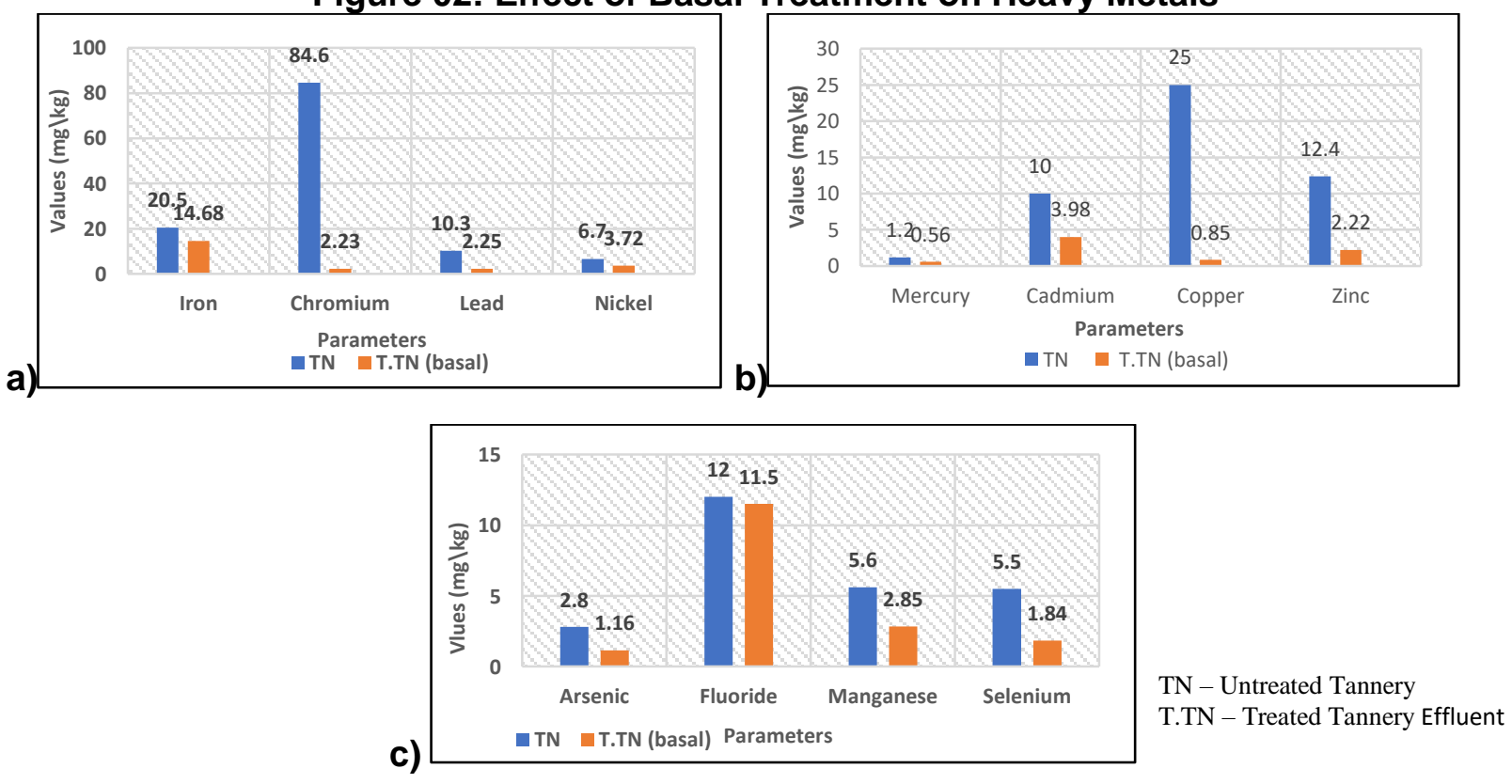

\section{Estimation of Nutritive Factor}

The NPK levels of the untreated tannery effluent showed $18.84 \mathrm{mg} / \mathrm{l}, 290 \mathrm{mg} / \mathrm{l}$ and $2.25 \mathrm{mg} / \mathrm{l}$ respectively. However, these levels were reduced as $N(1.5 \mathrm{mg} / \mathrm{kg}), P(5.98 \mathrm{~g} / \mathrm{kg})$ and $\mathrm{K}$ $(2.7 \mathrm{~g} / \mathrm{kg})$ respectively after treatment (Fig. 3). Shurky (2001) reported increase in soluble nitrogen content in wheat grains when irrigated with industrial effluents. Chhonkar et al. (2000) reviewed that addition of tannery effluent caused deflocculation of soil particles and increase in the $\mathrm{N}, \mathrm{P}$ and $\mathrm{K}$ levels of soil.

\section{Figure 03: Effect of Basal Treatment on NPK Levels}

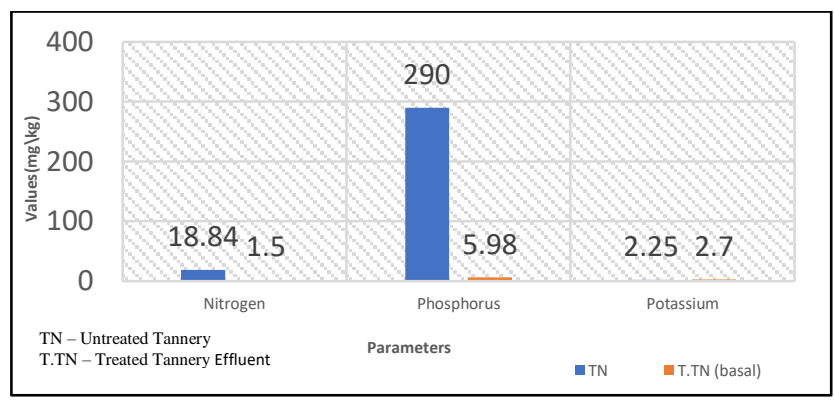

\section{Scanning Electron Microscopic view of treated tannery effluent $(\mathrm{TN}+\mathrm{CB}+\mathrm{CP}+\mathrm{NRK})$ on $30^{\text {th }}$ day}

Scanning Electron Microscope (SEM) is an eminent technique that can be used to investigate binding of metals to algae (Yan and Pan, 2002). In this study, the SEM was analysed on untreated and treated tannery effluent with basal application at $10 \mu \mathrm{m}$ (Plate 1a \& 1c) and $2 \mu \mathrm{m}$ 
(Plate $1 \mathrm{~b} \& 1 \mathrm{~d}$ )) particle size on $30^{\text {th }}$ day. The obtained results showed that the treated tannery effluent showed more smoothened surface modifications at both $10 \mu \mathrm{m}$ and $2 \mu \mathrm{m}$ particle sizes when compared to untreated tannery effluent. This could be due to the degradation of tannery and coir pith residue by cyanobacteria and the microbial consortia present in Nava Rasa Karaisal. SEM micro-graphs showed that, the algal cell before treatment had a normal shape with smooth and transparent external layer outside cell surface. After treatment, the cell with heavy metal adsorbed become slightly rough and corrugated textures and some particles were found on the surface of the cell wall (Kayil et al., 2015). Lombardi et al. (2002) described that cell wall is the first barrier to uptake of metals and that surface adsorption is an important mechanism of defense that eventually permits microalgae to tolerate high levels of toxic metals into the surrounding medium. SEM results revealed that most heavy metals were accumulated on the cell surface of the microalgae. SEM was performed to analyze the morphological changes $(20 \mu \mathrm{m})$ of organic manure and this could be due to the degradation of lignin like substances has been enhanced by the activity of microorganisms during incubation because of increased surface area and aeration.

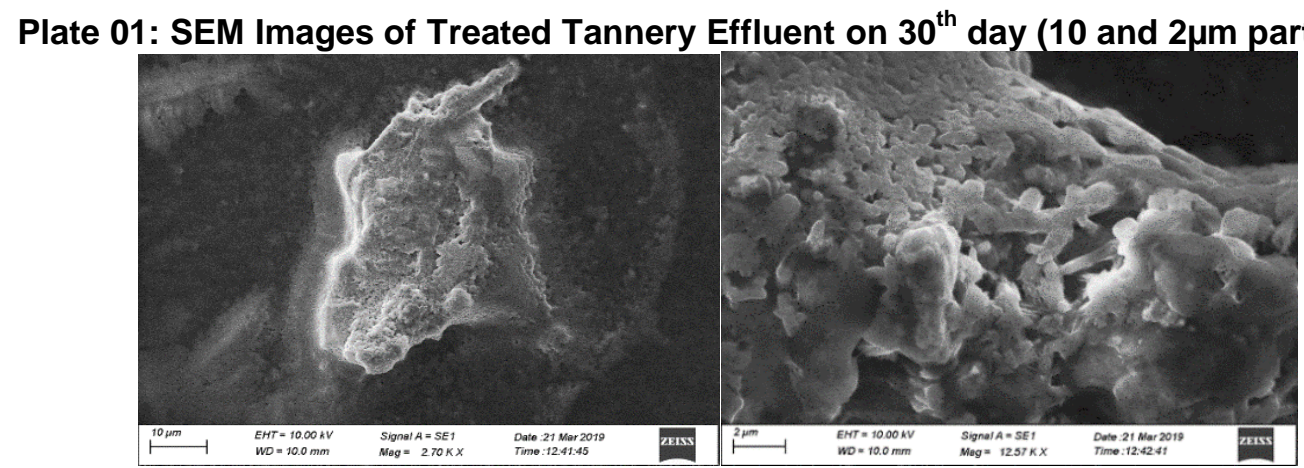

a) TN at $10 \mu \mathrm{m}$

b) TN at $2 \mu \mathrm{m}$

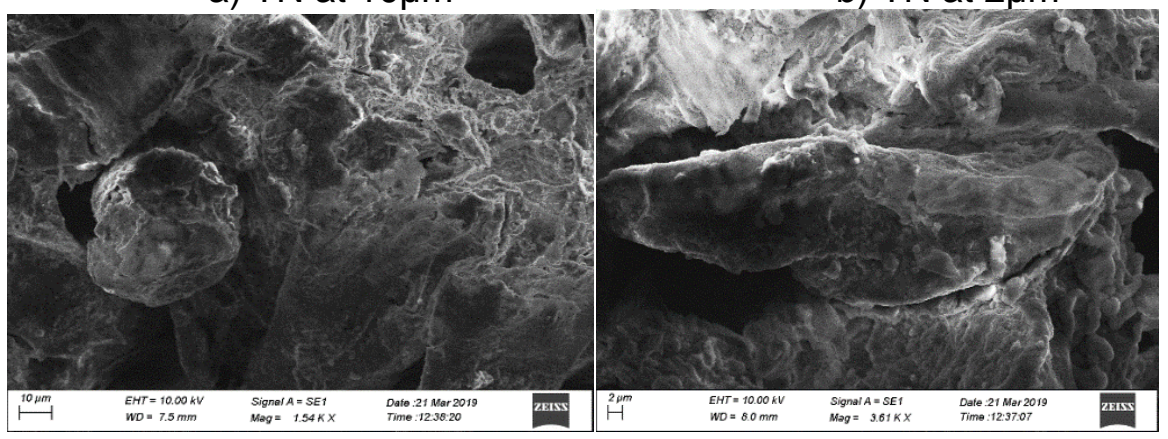

C) T.TN at $10 \mu \mathrm{m}$

d) T.TN at $2 \mu \mathrm{m}$

TN - Tannery effluent, CB- Cyanobacteria, CP- Coir Pith, NRK - Nava Rasa Karaisal TN - Untreated Tannerv: T.TN - Treated Tannerv Effluent

\section{Pot Experiment and Plant Growth}

The pot experiment was conducted to study the Sansevieria trifasciata plant growth at two different conditions and light intensities (Indoor plants at 500 lux light intensity, Outdoor plants at 15,000 lux light intensity) with fertilizer obtained from combined treatment as basal applications. The basal fertilizer was applied to pots as $20 \mathrm{~g}$ conc./pot and the plant growth was monitored on initial and $50^{\text {th }}$ day in terms of morphological parameters such as shoot width, shoot height and no. of leaves of the plant. On initial day, the morphometric parameters like width, height and no. of leaves were monitored for both indoor and outdoor plants. The obtained results showed that there was an increase in the morphometric parameters of the indoor plants when compared to outdoor plants. However, application of basal fertilizer showed better growth on $50^{\text {th }}$ day (Table $1 \& 2$ ).

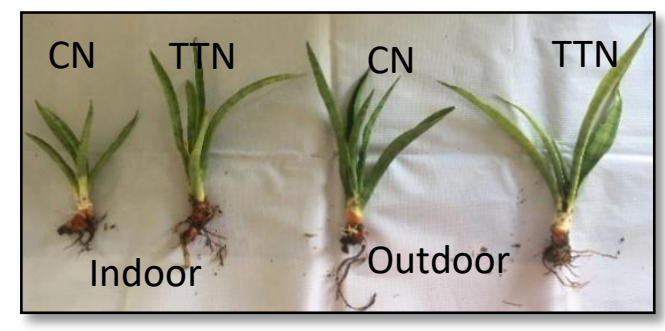

Plant growth $-0^{\text {th }}$ day

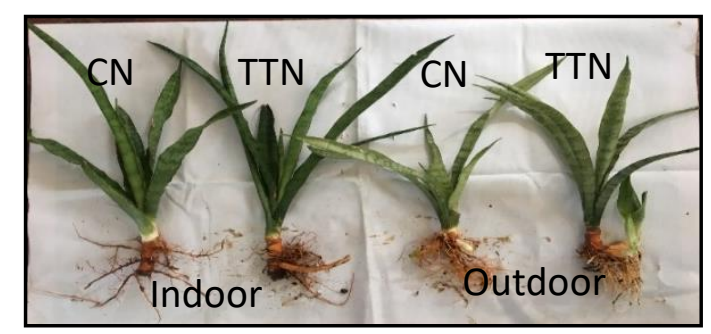

Plant growth $-50^{\text {th }}$ day 
Table 01: Morphometric Parameter Analysis on Initial Day

\begin{tabular}{|l|l|l|l|l|c|}
\hline$\#$ & Experimental & Treatment & \multicolumn{3}{|c|}{ Morphometric parameters } \\
\cline { 4 - 6 } & Condition & & Shoot width $(\mathrm{cm})$ & Shoot height $(\mathrm{cm})$ & No. of leaves \\
\hline 1. & OUTDOOR & CN & $4.85 \pm 0.14$ & $26.57 \pm 2.3$ & 5 \\
\cline { 3 - 6 } & $(15,000 L U X)$ & TTN & $4.88 \pm 0.16$ & $27.57 \pm 2.3$ & 5 \\
\hline 2. & $\begin{array}{l}\text { INDOOR } \\
n\end{array}$ & CN & $4.91 \pm 0.13$ & $27 \pm 3.2$ & 5 \\
\cline { 3 - 6 } & $(500 L U X)$ & TTN & $4.91 \pm 0.11$ & $27.85 \pm 2.8$ & 5 \\
\hline
\end{tabular}

Table 02: Morphometric Parameter Analysis on $50^{\text {th }}$ day

\begin{tabular}{|l|l|c|c|c|c|}
\hline$\#$ & \multirow{2}{*}{$\begin{array}{l}\text { Experimental } \\
\text { condition }\end{array}$} & \multirow{2}{*}{ Treatment } & \multicolumn{3}{|c|}{ Morphometric parameters } \\
\cline { 4 - 6 } & & CN & $5.18 \pm 0.16$ & $29 \pm 2.3$ & 5 \\
\hline \multirow{nnnyyy}{*}{2.} & OUTDOOR & Shoot width $(\mathrm{cm})$ & Shoot height $(\mathrm{cm})$ & No. of Leaves \\
\hline 2. & $(15,000 \mathrm{LUX})$ & TTN & $5.31 \pm 0.16$ & $32.14 \pm 2.3$ & 7 \\
\hline & INDOOR & CN & $5.18 \pm 0.16$ & $29.5 \pm 2.12$ & 5 \\
\hline
\end{tabular}

\section{Conclusion}

CN-Control; TTN - Treated Tannery Effluent

The adverse effect of tannery waste water is a challenging process for tannery industry and the surrounding environment. Therefore, to reduce the adverse effect of tannery industry discharge to the environment, an alternative, cost-effect and eco-friendly methods are a priority requirement. Thus in this study, the tannery effluent treated with coir pith, Nava Rasa Karaisal (NRK) and Lyngbya sp. (combined treatment) and untreated tannery effluent studied with respect to physiochemical parameters (BOD and COD) and heavy metals showed reduction in their levels. The SEM analysis $(10 \mu \mathrm{m}$ and $2 \mu \mathrm{m}$ particle size) also showed surface modifications and smoothening of the surface after treatment due to the degradation of particles present in the effluent by cyanobacteria and microbial population present in NRK. The morphometric characteristics and plant growth of Sansevieria trifasciata at $20 \%$ concentration as basal fertilizer in indoor pot experiment at $\mathbf{5 0 0}$ lux intensity showed increased plant growth in terms of plant height, width and no. of leaves on $50^{\text {th }}$ day when compared with outdoor plants at 15,000 lux light intensity. Thus from the above results, it can be concluded that the pollutants present in untreated tannery effluent can be reduced after combined treatment of cyanobacteria, coir pith and the microbial consortia (from NRK) and the biomass obtained from combined treatment can be used as a organic manure for plant growth.

\section{Acknowledgement}

The authors are grateful to Model Organic Farm (MOF), Bharathidasan University, Tiruchirappalli, Tamilnadu for the facility and completion of this work.

\section{References}

1. Abirami, S.; Srisudha, S. and P Gunasekaran. (2013) Comparative Study of Chromium Biosorption using Brown, Red and Green Macro Algae. Int. J. Bio Phar Res. 2013; 4: 115129.

2. Alebelabebe. (2010) Impacts of chromium from tannery effluent and evaluation of alternative treatment option. Journal of environmental protection, Vol.1: 53-58.

3. Anamika, A.; Singh, H. P. and Rai, J. P. N. (2013) Bioremediation of tannery effluent by using Pseudomonas fluroscens and Eichhornia crassipes and its effect on wheat seed germination and plant growth. G- journal of Environmental Science and Technology. 1(1): 20-23.

4. Anandhraj, B; Krishna Moorthy, S. and Malliga, P. (2012) Studies on the degradation of coir pith using fresh water Cyanobacterium Oscillatoria annae BDU 6 and its lignolytic enzyme activity in response to coir pith degradation. Int. J. Curr. Sci. 78-86.

5. AOAC. (2000) Official method of Analysis, $17^{\text {th }}$ Ed. Agricultural chemistry, Washington, DC.

6. APHA. (1998) Standard methods for the examination of water and wastewater. American Public Health Association, Washington, DC. $17^{\text {th }}$ edition.

7. Chhonkar, P. K.; Datta, S. P. Joshi, H. C. and Pathak. H. (2000) Impact of industrial effluents on soil health agriculture. Journal of Sci. Ind. Res. 59: 446- 454.

8. David Noel S; Rajan, M.R. (2012) Assessment of dye industry effluent for irrigation and its impact on ground water quality at Chinnalapatti. J. Eco toxicol Envron. Monit. 22: 395-399. 
9. Ganesh R. and Ramanujam, R.A. 2(009) Biological waste management of leather tannery effluents in India: current options and future research needs. Int. J. Environmental Engineering. 1(2): 166-167.

10. Gargi Pachauri, Prem Singh Bugasara, Meenakshi Yadav, Murtaza Abid, M.M. Abid Ali Khan and Raaz. K. (2017) Snake Plant (Sansevieria trifasciata): Imminent Classically Versatile House Indoor Detoxifier. Journal of biological and chemical research. 34(2): 923927.

11. Gautam AK; Avasthi S. and Bhadauria, R. (2012) Colletotrichum sansevieriae on Sansevieria trifasciata - a report from Madhya Pradesh, India. Plant Pathology \& Quarantine. 2(2): 190-192

12. Hald, P. M. (1947) The flame photometer for the measurement of sodium and potassium in biological materials. J. Biol. Chem. 167: 499.

13. Heather, L.; Papinchak, E. Jay Holcomb, Teodora Orendovici Best. and Dennis R. Decoteau. (2009) Effectiveness of Houseplants in Reducing the Indoor Air Pollutant Ozone. Horti technology. 19(2): 286-290.

14. Jackson, R. G., L. Eng-kial, Y. Li, K. Mariusz, S. Goran, A. J. David Ashford and D. J. Bowles (2001) Identification and biochemical characterization of an Arabidopis sp. indole-3acetic acid glucosyl transferase. Journal of Biological chemistry. 276 (6): 4350-4356.

15. Jenny S. and Malliga, P. (2016) Assessment of different concentrations of organic manure on the growth and yield of Solanum lycopersicum L. (tomato). International Journal of Innovative Research in Science, Engineering and Technology. 5(3): 3722-3731.

16. Julie S. Berame, Sheena Mae E. Cuenca, Diana Rose P. Cabilin and Marycris L. Manaban (2017) Journal of Phylogenetics and Evol. Biol.5:3.

17. Kayil Veedu Ajayan; Muthusamy Selvaraju, Pachikaran Unnikannan \& Palliyath Sruthi. (2015) Phytoremediation of Tannery Wastewater Using Microalgae Scenedesmus Species. International journal of phytoremediation. 17(10): 907-916

18. Krishna Moorthy. S; Subramaniyan, V. and Malliga, P. (2012) Effect of Coir Pith Based CyanobacterialBiofertilizer on Morphological and Yield Characters of Aloe Barbadensis Miller in Pot Experiment. Journal algal biomass utilization. 3(2): 33-41

19. Lakshmi Karuppaiah; Rajakumar Suntharam, Malliga Perumal. (2015) Bioremediaton of Tannery Effluent Using Lyngbya Sp. with Coir Pith. International Journal of Science and Research. 4(1): 2736-2743.

20. Lombardi, A. T.; Vieira, A. V. H. and Sartori, L. A. (2002) Mucilaginous capsule adsorption and intracellular uptake of copper by Kirchneriella aperta (Chlorococcales). J Phycol. 38: 332-337.

21. Murali Shankar. A; Henciya, S. and Malliga, P. (2013) Bioremediation of tannery effluent using fresh water cyanobacterium Oscillatoria annae with coir pith. International journal of environmental sciences. 3(6): 1881-1890.

22. Rippka R; Deruelles J, Waterbury JB, Herdman M, and Stanier R.Y. (1979) Generic assignments, strain histories and properties of pure cultures of cyanobacteria. J. Gen. Microbiol.111:1-61.

23. Sanjay Kumar Dubey; Jaishree Dubey, Sandeep Mehra, Pradeep Tiwari and Bishwas, A. J. (2011) Potential use of cyanobacterial species in bioremediation of industrial effluents, African Journal of Biotechnology. 10(7): 1125-1132.

24. Selvi, A.; Anjugam, E. Devi, R. Madhan, B. Kannappan, S. and Chandrasekaran, B. C. (2012) Isolation and characterization of bacteria from tannery effluent treatment plant and their tolerance to heavy metals and antibiotics. Asian j. Exp. Biol. Sci. 3 (1): 34-41.

25. Sharma, S. and P. Malaviya. (2011) Bioremediation of tannery wastewater by Aspergillus niger SPFSL 2 - a isolated from tannery sludge. J. Basic Appl. Sci. 2: 88-93.

26. Shukry, W. M. (2001) Effect of industrial effluents polluting the river Nile on growth, metabolism and productivity of Triticum aestivum and Viciafaba plants. Pakistan Journal of Biological Sciences. 4: 1153-1159.

27. Srinivas, G. B. and Estari, M. (2012) Studies of efficacy of immobilized bacteria in tannery effluent treatment. J. Bio. innov. 2 (2): 33-44.

28. Yan, H. and Pan, G. (2002) Toxicity and bioremediation of copper in three green microalgae species. Chemosphere. 49: 471-476. 